\title{
Research on the "Dual" Impact of COVID-19 Epidemic and China-US Trade Frictions on Enterprises' Relocation --Based on survey data of 413 companies
}

changhao zhu ( $\nabla$ zchbb45445@126.com )

Anhui University of Finance and Economics https://orcid.org/0000-0002-0293-1517

maosen xia

Anhui University of Finance and Economics

lingling Jiang

Anhui University of Finance and Economics

\section{Research Article}

Keywords: COVID-19 epidemic,China-US trade frictions,feature selection,enterprises, relocation

Posted Date: February 17th, 2022

DOI: https://doi.org/10.21203/rs.3.rs-1118628/v1

License: (c) (1) This work is licensed under a Creative Commons Attribution 4.0 International License.

Read Full License 


\title{
Research on the "Dual" Impact of COVID-19 Epidemic and China-US Trade Frictions on Enterprises' Relocation -Based on survey data of 413 companies
}

\author{
Xia Mao-sen ${ }^{1}$, Zhu Chang-hao ${ }^{1}$, Jiang Ling-ling ${ }^{2}$ \\ (1. Statistics of Applied Mathematics, Anhui University of Finance and Economics, Bengbu \\ 233041,China; 2. School of Accountancy, Anhui University of Finance and Economics, Bengbu \\ 233041,China)
}

\begin{abstract}
In response to COVID-19 epidemic and China-US trade frictions, based on the survey data of 413 companies, starting from the descriptive statistical analysis of whether the companies with different characteristics have migrated or not, with the help of the feature selection method in machine learning, The balanced characteristics of the enterprise migration survey data were analyzed by feature selection, and finally 13 important characteristic variables that affect whether the company migrated or not were selected from 102. On this basis, the effects of the dual effects of COVID-19 epidemic and China-US trade friction on the migration of enterprises were further investigated and analyzed through the Probit model. The results show that the growth rates of import and export and export in the first and second half of 2020 have a significant impact on the migration of enterprises. Among them, the growth rate of import and export in the first and second half of the year has a positive and negative effect on the migration of enterprises, while the growth rate of exports The impact on the company's relocation is negative. In addition, the type of business economy, the proportion of foreign trade, and the emotional characteristics of 2021 orders also have a significant impact on the company's relocation.
\end{abstract}

Key words : COVID-19 epidemic; China-US trade frictions; feature selection; enterprises' relocation

CLC number: F270

Document code: A

\section{一、Introduction}

Since 2018 , the US gover ${ }^{1}$ mment has unilaterally bypassed the WTO and implemented the "us first" trade protection policy, and Sino US trade frictions have been escalating. The first is to impose tariffs on China's key advanced manufacturing fields such as chemical industry, medicine, motor engine and information and communication technology, and then implement the crackdown

Fund Project:Humanities and social sciences research youth project of the Ministry of Education"Research on the influence mechanism of individual resource dominance rule preference on cooperative equilibrium "(17YJC630175)Anhui philosophy and social science planning project"Research on the construction and realization path of diversified collaborative targeted poverty alleviation mechanism from the perspective of social capital"(AHSKQ2017D01).

Introduction to the author:xia mao-sen,man,Anhui Chaohu people,doctor,Professor of Anhui University of Finance and economics. Research interests: resource allocation management and institutional evolution; Zhu chang-hao,man,Jiangsu Yangzhou people,master,Research interests: macroeconomic statistics(Corresponding author);

Jiang ling-ling,woman,Anhui Bengbu people,master,Associate professor of Anhui University of Finance and economics. Research direction: industrial innovation performance evaluation. 
policy on China's Internet technology enterprises ${ }^{[1]}$ (Lin Yong-hui etc, 2017) The increasing trade friction has brought a serious negative impact on the external ecological environment of Chinese enterprises.The novel coronavirus pneumonia outbreak in late 2019 (COVID-19 or epidemic situation) has brought great impact on the global economy and society. The development of human society has encountered unprecedented challenges, which has brought severe tests to the global enterprises' production, operation and development.

In the face of the "double" external impact of Sino US trade friction and the outbreak of the epidemic, the production and operation of Chinese enterprises will undoubtedly be squeezed to a certain extent.In terms of enterprise structure, in addition to state-owned enterprises and private enterprises, China also includes a large number of joint ventures and foreign-funded enterprises.As we all know, foreign capital and joint ventures have natural liquidity in capital flow, even partial or overall relocation. Then, in order to seek new development space or meet the "better growth needs" of enterprises under various trade-offs, will enterprises choose to move out to get rid of the current dilemma?In other words, driven by interests, will enterprises that have "settled down" in China choose to migrate to avoid economic risks, technical barriers or seek new development space?Do enterprises of different ownership types, scales and industries have significantly different characteristics of relocation? Under the external impact of the epidemic and trade friction, what are the important factors affecting the relocation of enterprises, and how do they affect the relocation of enterprises?For a while, all kinds of questions abound, and the relocation of enterprises has become a hot topic, but also an issue to be further studied.In view of this, this paper will focus on the issue of the relocation of enterprises under COVID-19 and Sino US trade friction. Through the micro survey data analysis of the provincial special enterprises' relocation, we will further investigate the relocation characteristics and influencing factors of enterprises under the external impact of "double".

\section{二、Literature Review}

Enterprise relocation is a complex system problem.First of all, from the conceptual connotation, enterprise relocation mainly refers to the relocation of enterprises in one region to another region, and the region can be a country, a province, or a city ${ }^{[2]}$ (Wang Xiao-juan etc , 2006 ).The enterprise relocation in this paper mainly refers to the migration of Chinese related enterprises to foreign countries or Western China.The existing literature on enterprise relocation 
mainly focuses on the motivation of enterprise relocation, including the impact of market environment, cost constraints, policy driving and location selection on enterprise relocation.

In terms of market environment, when it changes, enterprises need to choose strategies that match the environment in order to obtain competitive advantage ${ }^{[2]}$ (Wang Xiao-juan etc, 2006).In other words, the motivation of enterprise relocation is to seek a better match between their own enterprise development and the external market environment. The external market environment mainly includes market demand and supply, as well as the corresponding investment and financing environment $^{[4]}$ (Li Yan-jun etc, 2018).

In terms of cost constraints, price constraints such as labor, land and raw materials are the key.Under the condition of constant return to scale, the difference of production cost between regions will lead to the relocation of enterprises, that is, when the production cost in more developed regions increases relatively and the production in less developed regions decreases relatively, enterprises in developed regions will migrate to less developed regions.At the same time, market advantage and location resource attraction will also lead to enterprise migration ${ }^{[5]}$ (Zheng Xin and Chen Yao, 2012) .The international difference of labor wage level in factor cost plays an important role in enterprise relocation, especially when the wage gap between the two countries is large enough to offset the association advantage between the enterprise and the current enterprise, enterprise relocation is profitable ${ }^{[6]}$ ( Teng Tian Chang-jiu etc, 2011 ) .In migration decision-making, the environmental change cost and migration cost faced by enterprises are the basis and key of decision-making ${ }^{[7]}$ ( Xu Li-ping etc , 2019 ) .Specifically, cross regional transportation costs, communication costs between enterprise headquarters and factories, and interregional tax policies will affect enterprise relocation ${ }^{[8]}$ (Liang Qi etc, 2012). In addition, the net outflow of high-tech personnel will also promote the relocation of enterprises ${ }^{[9]}$ (Liminta LG, 2018 ）.Plant R (2007) It is considered that there is a symbiotic relationship between Venture Capital Agglomeration and enterprise relocation, and venture capital transfer will hinder enterprise relocation decision-making ${ }^{[10]}$.

In the study of relocation of different types of enterprises,Liu zheng-zhong (2020) think, In recent years, China's manufacturing industry has moved abroad, mainly due to the rise of domestic production $\operatorname{costs}^{[11]}$.As for the relocation of cluster enterprises, when the failure of cluster network and uneconomical agglomeration lead to the decline of the role of cluster shared resources, 
enterprises will choose to relocate ${ }^{[2]}$ (Wang Xiao-juan etc, 2006) .The limited regional resources such as land and labor and the heterogeneity of cluster enterprises will lead to the dissipation of agglomeration advantages, which will lead to the relocation of cluster enterprises ${ }^{[12]}$ (Wu Bo etc, 2012 ).In terms of relocation of private enterprises, Lin bi-yue (2012) think, The higher the ownership concentration and the more perfect the strategic consulting organization, the higher the possibility of the relocation of the headquarters of the enterprise ${ }^{[13]}$.

In addition, in terms of policy factors and location selection, researchers of institutional economics believe that enterprise relocation cannot be separated from its social system and social network $^{[14]}$ (Xu Liang, 2014), Thus, it is constrained by the interaction between the policy effect (especially the environmental governance policy) under the institutional system, the relocation cost and the location choice.Li yan-jun（2015) Research shows, Government policy factors have the most significant impact on the migration of resource-based enterprises ${ }^{[15]}$.Yan ben-jian (2014) think, In the context of regional coordinated development, the government's industrial transfer policy has promoted enterprise migration to a great extent ${ }^{[16]}$.In terms of environmental governance policies, Nachtigall D (2019) think, The increase of carbon price under the regional climate policy urges enterprises to increase investment in emission reduction, resulting in a locking effect, which will lead to the relocation of enterprises ${ }^{[17]}$.Wang ding-xing (2019) Also think, The enhancement of China's environmental regulation will improve the migration probability of enterprises in the county ${ }^{[18]}$. In addition, the location selection of enterprise migration is often based on the development conditions and characteristics of the target location. The corresponding characteristic conditions mainly include the policy characteristics, expansion space, transportation and public facilities of the location.Zhou zheng-zhu (2015) think, With the impact of policies on environment, land and employment, enterprises in the central area of big cities continue to spread to the near and outer suburbs, resulting in the accelerating suburbanization of manufacturing industry ${ }^{[19]}$.Yang kai-zhong ( 2019 ) think, The transportation conditions of interregional, core and marginal areas will affect the migration threshold of heterogeneous enterprises $^{[20]}$.

According to the summary, there are many factors affecting the relocation of enterprises.For a long time, scholars at home and abroad have done in-depth research on the cost constraints, institutional environment and other factors of enterprise relocation, and the research results are 
fruitful.However, there are relatively few existing studies on enterprise relocation based on micro enterprise research data, and there are few empirical studies on the impact of external shocks on enterprise relocation from the perspective of sudden epidemic and Sino US trade friction.In addition, from the perspective of sample data, enterprise relocation has obvious unbalanced classification characteristics, because relatively speaking, the number of relocated enterprises is usually a minority category, so whether enterprises relocate or not has become an unbalanced classification problem. Then, how to conduct in-depth research on the current enterprise relocation problem with unbalanced classification characteristics has become a scientific proposition with important research significance and urgent need to be studied and solved.Therefore, based on the survey data of micro enterprise migration and the feature selection method in machine learning, based on the analysis of the feature selection of non-equilibrium sample data, this paper further studies the relocation characteristics and influencing factors of enterprises under the dual influence of COVID-19 and Sino US trade frictions by further econometric models.

\section{三、Data source and sample composition}

\section{(一) Data sources}

In order to understand and deal with the impact of COVID-19 and Sino US trade friction on the relocation of enterprises, A province launched a special investigation on the relocation of enterprises.The survey starts on May 10, 2020 and ends on May 20, 2020.In the form of online electronic questionnaire, the heads of 417 enterprises or heads of comprehensive management departments in a province were investigated.The questionnaire is carried out in the form of formal special survey. While ensuring the authority of the survey, it effectively obtains first-hand survey data from enterprises, effectively ensuring the authenticity, reliability and completeness of the data.The survey includes the basic information of enterprises, the situation of enterprise orders, the impact of COVID-19 and Sino US trade friction on enterprises, the measures to be taken by enterprises, and the proportion of enterprises' relocation and relocation capacity. There are altogether 26 problems. It fully reflects the basic situation and relocation wishes of enterprises in A Province under the influence of COVID-19 and Sino US trade friction.

\section{(二) Sample composition}

Among the 417 enterprises interviewed, 4 enterprises with serious lack of key data, such as lack of basic information and lack of relocation, were excluded. Finally, the valid sample data of 
413 enterprises remained. 107 survey data indicators were obtained by sorting out the questionnaire. The specific composition is shown in the table below:

Table1 survey sample data indicators

\begin{tabular}{|c|c|c|}
\hline 1st indices & minor indexes & $\begin{array}{c}\text { Number } \\
\text { of } \\
\text { indicator } \\
\text { s (PCs.) }\end{array}$ \\
\hline $\begin{array}{l}\text { Enterprise } \\
\text { basic } \\
\text { information }\end{array}$ & $\begin{array}{l}\text { Enterprise name } \\
\text { Enterprise code } \\
\text { Questionnaire completed by (name, department and position, contact } \\
\text { number) } \\
\text { Industry ( } 8 \text { categories of agricultural and food products, } \\
\text { electromechanical instruments, etc.) } \\
\text { Enterprise category (production / processing / manufacturing } \\
\text { enterprises, circulation trade enterprises, others) } \\
\text { Brand type (OEM processing, independent brand, both OEM and } \\
\text { independent brand, others) } \\
\text { Economic type (state-owned, private, Hong Kong, Macao, Taiwan } \\
\text { and foreign-funded enterprises) } \\
\text { Proportion of foreign trade (0-100\%) } \\
\text { Enterprise scale (less than } 50 \text { persons, } 50 \text { (inclusive) - } 200 \text { persons, } \\
200 \text { (inclusive) - 500 persons and more than } 500 \text { persons) } \\
\text { Business income of enterprises in } 2019 \text { (less than } 10 \text { million yuan, } \\
10-50 \text { million yuan, } 50-100 \text { million yuan, 100-1 billion yuan and more } \\
\text { than } 1 \text { billion yuan) } \\
\text { Foreign trade import and export in the first half of } 2020 \text { (increase and } \\
\text { decrease of import, export and import and export) }\end{array}$ & 19 \\
\hline $\begin{array}{l}\text { Novel } \\
\text { coronaviru- } \\
\text { pneumonia } \\
\text { and Sino } \\
\text { US trade } \\
\text { friction }\end{array}$ & $\begin{array}{l}\text { COVID-19's impact on enterprises (multiple choice questions, } \\
\text { including order reduction, low employee reemployment rate, delayed } \\
\text { start up, etc.) } 11 \text { options. } \\
\text { The comprehensive impact of COVID-19 and Sino US economic and } \\
\text { trade frictions on enterprises (multiple choice items, including raw } \\
\text { materials, supply chain breakage, market order reduction, } \\
\text { transportation and Logistics Impact } 13 \text { options) }\end{array}$ & 24 \\
\hline $\begin{array}{l}\text { Enterprise } \\
\text { response } \\
\text { measures }\end{array}$ & $\begin{array}{l}\text { Enterprise response measures (multiple choice questions, including } 11 \\
\text { options such as overtime, flexible employment, implementation of } \\
\text { intelligent office, remote office, automatic production, etc.) } \\
\text { The most preferred tax guarantee method for enterprises } \\
\text { Favorable factors for current foreign trade development (multiple } \\
\text { choice questions, including } 8 \text { options such as obvious advantages in } \\
\text { scientific and technological innovation, obvious tax reduction and fee } \\
\text { reduction, and cost reduction) }\end{array}$ & 20 \\
\hline
\end{tabular}




\begin{tabular}{l|l|l}
$\begin{array}{l}\text { Enterprise } \\
\text { future } \\
\text { expectation }\end{array}$ & $\begin{array}{l}\text { Expected foreign trade import and export orders in the second half of } \\
2020 \text { (increase and decrease of import, export and import and export) } \\
\text { Emotional characteristics of 2021 import and export orders } \\
\text { (optimistic, unchanged, pessimistic and others) }\end{array}$ & 7 \\
\hline & $\begin{array}{l}\text { Relocation of enterprises (multiple choice questions, including 16 } \\
\text { options such as the European Union, the United States and Western } \\
\text { China) }\end{array}$ & \\
$\begin{array}{l}\text { Relocation } \\
\text { of } \\
\text { enterprises }\end{array}$ & $\begin{array}{l}\text { Promotion factors of enterprise relocation (multiple choice questions, } \\
\text { including 10 options such as labor cost and land cost) } \\
\text { Obstacles to enterprise relocation (multiple-choice questions, } \\
\text { including 10 options such as insufficient supporting industrial chain } \\
\text { and lack of local human resources) } \\
\text { Willingness to move out (move out, no move out) }\end{array}$ & 37 \\
\hline \multicolumn{1}{|c|}{107} & \\
\hline 合计 & \multicolumn{1}{|c|}{107} \\
\hline
\end{tabular}

Among them, each option of multiple topics is expressed in the form of 0 or 1 ( 0 means that the item is not selected, and 1 means that the item is selected). Finally, if there are 16 options, 16 corresponding indicators will be formed. On the basis of sorting out the survey sample data, 107 relatively complete indicators of 413 companies were preliminarily obtained.In addition, the five indicators of enterprise name, enterprise code and the person completing the questionnaire (name, department and position, contact number) are further removed, because except for the Department position, they are basically unique values, and the Department position of the person filling in is basically the person in charge of the marketing department. In the survey, the person filling in is more similar and has less impact on relocation, so these five indicators are excluded. Finally, 102 index data of 413 enterprises were obtained.

\section{四、An empirical analysis on the impact of enterprise relocation}

\section{(一) Sample reliability and validity analysis}

The reliability and validity of 413 samples were analyzed. The results show that Cronbach a The reliability coefficient is 0.845 , and the overall reliability of the questionnaire is good. In the kmo and Bartlett test, the kmo value is 0.917 , the approximate chi square value of the corresponding Bartlett sphere test is 9156.495 , and the corresponding $\mathrm{p}$ value is approximately 0.000 , less than $5 \%$. The overall structural validity of the questionnaire is good.

\section{(二) Descriptive statistical analysis of enterprise relocation}

According to the sample data, under the dual influence of COVID-19 and Sino US trade frictions, 387 out of 413 surveyed enterprises had no relocation plan, accounting for $93.7 \%$. 
Correspondingly, 26 enterprises have planned to move out in the next three years, accounting for $6.3 \%$. From the target variables of whether enterprises move out or not, the characteristics of sample unbalanced data are obvious.

The classification characteristics of relocated enterprises are shown in Table 2 below. As can be seen from table 2, among the enterprise industry types, those whose migration accounts for more than $7 \%$ of the total investigated enterprises include wood, paper, non-metallic (7.69\%), textile shoes and hats $(7.35 \%)$ and electromechanical instruments $(7.09 \%)$. In terms of the absolute number of relocated enterprises, the electromechanical instrument industry has the largest number of relocated enterprises, with a total of 9 , accounting for $34.62 \%$ of the 26 relocated enterprises. In terms of enterprise categories, 19 production, processing and manufacturing enterprises have moved out, accounting for $6.91 \%$ of the surveyed enterprises. In terms of enterprise ownership types, there are two enterprises from Hong Kong, Macao and Taiwan, accounting for the largest proportion (10\%) in the investigated ownership categories, followed by private enterprises, accounting for $7.26 \%$, and foreign-funded enterprises, accounting for $5.80 \%$, lower than domestic private enterprises.

In terms of enterprise scale, 14 enterprises with more than 500 employees have moved out, accounting for the largest proportion (8.48\%), while enterprises with small and medium-sized employees (50 (including) 200) have the smallest proportion (1.69\%); Eight enterprises with less than 50 employees have moved out, including two with an output value of RMB 100-1 billion, four with an output value of less than RMB 10 million, one with an output value of RMB 10-50 million and one with an output value of RMB 50-100 million. In terms of operating income, 8 enterprises with more than 1 billion yuan moved out, accounting for $7.69 \%$ of the similar enterprises surveyed; Enterprises with 50 million yuan to 100 million yuan accounted for the largest proportion $(9.09 \%)$.

Table2 Basic characteristics of relocated Enterprises

\begin{tabular}{c|c|c|c|c}
\hline $\begin{array}{c}\text { Attribute } \\
\text { characterist } \\
\text { ics }\end{array}$ & Category & $\begin{array}{c}\text { Total } \\
\text { number of } \\
\text { enterprise } \\
\mathrm{s}\end{array}$ & $\begin{array}{c}\text { Migration } \\
\text { number }\end{array}$ & $\begin{array}{c}\text { Proportio } \\
\mathrm{n}\end{array}$ \\
\hline $\begin{array}{c}\text { Enterprise } \\
\text { industry }\end{array}$ & $\begin{array}{c}\text { Agricultural and food } \\
\text { products }\end{array}$ & 38 & 2 & $5.26 \%$ \\
\cline { 1 - 3 } & &
\end{tabular}




\begin{tabular}{|c|c|c|c|c|}
\hline \multirow[t]{7}{*}{ type } & $\begin{array}{c}\text { Electromechanical } \\
\text { instrument }\end{array}$ & 127 & 9 & $7.09 \%$ \\
\hline & Mineralized metal & 82 & 5 & $6.10 \%$ \\
\hline & Textile shoes and hats & 68 & 5 & $7.35 \%$ \\
\hline & Rubber and plastic leather & 30 & 2 & $6.67 \%$ \\
\hline & Toy furniture & 20 & 1 & $5.00 \%$ \\
\hline & Wood paper nonmetal & 26 & 2 & $7.69 \%$ \\
\hline & other & 22 & 0 & $0 \%$ \\
\hline \multirow{3}{*}{$\begin{array}{l}\text { Enterprise } \\
\text { category }\end{array}$} & $\begin{array}{l}\text { Production / processing / } \\
\text { manufacturing enterprises }\end{array}$ & 275 & 19 & $6.91 \%$ \\
\hline & $\begin{array}{l}\text { Circulation trade } \\
\text { enterprise }\end{array}$ & 120 & 7 & $5.83 \%$ \\
\hline & other & 18 & 0 & $0.00 \%$ \\
\hline \multirow{4}{*}{$\begin{array}{l}\text { Ownership } \\
\text { type }\end{array}$} & state-owned enterprise & 76 & 2 & $2.63 \%$ \\
\hline & private enterprise & 248 & 18 & $7.26 \%$ \\
\hline & $\begin{array}{c}\text { Enterprises in Hong } \\
\text { Kong, Macao and Taiwan }\end{array}$ & 20 & 2 & $10.00 \%$ \\
\hline & foreign enterprise & 69 & 4 & $5.80 \%$ \\
\hline \multirow{4}{*}{$\begin{array}{l}\text { Enterprise } \\
\text { employees }\end{array}$} & Less than 50 people & 112 & 8 & $7.14 \%$ \\
\hline & $\begin{array}{l}50 \text { (inclusive) } \sim 200 \\
\text { persons }\end{array}$ & 59 & 1 & $1.69 \%$ \\
\hline & $\begin{array}{l}\text { 200(inclusive) } \sim \\
\text { 500persons }\end{array}$ & 77 & 3 & $3.90 \%$ \\
\hline & More than 500 people & 165 & 14 & $8.48 \%$ \\
\hline \multirow{6}{*}{$\begin{array}{l}\text { Business } \\
\text { income }\end{array}$} & Less than 10 million yuan & 57 & 5 & $8.77 \%$ \\
\hline & $10 \sim 50$ million yuan & 24 & 2 & $8.33 \%$ \\
\hline & $\begin{array}{c}50 \text { million to } 100 \text { million } \\
\text { yuan }\end{array}$ & 33 & 3 & $9.09 \%$ \\
\hline & 100-1 billion yuan & 192 & 8 & $4.17 \%$ \\
\hline & More than 1 billion yuan & 104 & 8 & $7.69 \%$ \\
\hline & Missing value & 3 & - & - \\
\hline
\end{tabular}

\section{（三） Analysis on the feature selection affecting enterprise relocation}

According to the 102 index data of 413 enterprises (excluding 5 variables on the basis of 107 variables), and further with the help of the feature selection method in machine learning, this paper attempts to carry out unbalanced feature selection analysis on the enterprise relocation data, and test the robustness of the feature selection without balance processing and after balance processing, so as to eliminate redundancy and precision, Select the characteristic variables that have an important impact on the relocation of enterprises to improve the accuracy of analysis. The specific feature selection analysis design and results are as follows. 


\section{Feature selection analysis and design}

The design of feature selection analysis mainly includes the following six aspects: first, determine the target variables and input variables of feature selection analysis. This paper takes the relocation of enterprises in the survey data as the target variable and the other 101 variables as the input variable.

Second, the feature analysis dimension of emigration sample data. It is mainly considered from three aspects: first, feature selection analysis under unbalanced data; Second, feature selection analysis after balance processing; The third is the comparison of the two results and the test and analysis of the effect of variable screening.

Third, preliminary preprocessing of sample data. In this paper, the sample data is relatively complete and there are few missing values. Only three data of enterprise operating income and five data of foreign trade share are missing. For this, the missing values are processed with the help of random forest interpolation method. In addition, the continuous variable data shall be standardized. The classified variables are processed by one hot coding.

Fourth, data balance processing. Due to the large unbalanced difference between the data of enterprise relocation and non relocation (accounting for $6.3 \%$ and $93.7 \%$ respectively). Therefore, this paper selects the borderline smote method with better balance boundary treatment for balance treatment.

Fifth, the feature selection method is determined. Among the filtering method, recursive feature elimination method and embedding method of feature selection method, this paper selects the feature selection method based on gradient tree model in the embedding method with good universality, nonlinear determination of weight coefficient and flexible model algorithm as the benchmark model for feature analysis of enterprise relocation.

Sixth, the effect analysis of feature selection. On the basis of dividing the data set into training set and test set, investigate the feature selection under unbalanced data and balanced data respectively, train the model on the training set, and compare and analyze through the test set. The benchmark model of classification selects the XGboost classification model with built-in regularization.

\section{Feature selection analysis results}

Based on the data preparation and preprocessing of sample data (including the setting of 
classification variables and the standardization of continuity variables), the feature selection and test set prediction accuracy results of enterprise relocation are obtained by programming with Python software. See Table 3 below for details:

Table 3 feature selection results and test set prediction accuracy of enterprise relocation

\begin{tabular}{|c|c|c|c|c|c|c|c|c|c|}
\hline \multirow[b]{2}{*}{$\begin{array}{l}\text { Seria } \\
1 \\
\text { num } \\
\text { ber }\end{array}$} & \multirow[b]{2}{*}{$\begin{array}{l}\text { Proport } \\
\text { ion of } \\
\text { trainin } \\
\text { g set }\end{array}$} & \multicolumn{4}{|c|}{$\mathrm{CV}=5$} & \multicolumn{4}{|c|}{$\mathrm{CV}=10$} \\
\hline & & $\begin{array}{l}\text { Nonequilibr } \\
\text { ium_ } \\
\text { Number of } \\
\text { variables }\end{array}$ & $\begin{array}{l}\text { Nonequilibr } \\
\text { ium_- } \\
\text { Average } \\
\text { prediction } \\
\text { accuracy }\end{array}$ & $\begin{array}{c}\text { Balan } \\
\text { ce_ } \\
\text { Numb } \\
\text { er of } \\
\text { variab } \\
\text { les }\end{array}$ & $\begin{array}{c}\text { Balanc } \\
\text { e_ } \\
\text { Avera } \\
\text { ge } \\
\text { predict } \\
\text { ion } \\
\text { accura } \\
\text { cy }\end{array}$ & $\begin{array}{c}\text { Non } \\
\text { equi } \\
\text { libri } \\
\text { um_ } \\
\mathrm{Nu} \\
\text { mbe } \\
\text { r of } \\
\text { vari } \\
\text { able } \\
\mathrm{s}\end{array}$ & $\begin{array}{c}\text { Noneq } \\
\text { uilibri } \\
\text { um_ } \\
\text { Avera } \\
\text { ge } \\
\text { predic } \\
\text { tion } \\
\text { accura } \\
\text { cy }\end{array}$ & $\begin{array}{c}\text { Bala } \\
\text { nce_ } \\
\text { Num } \\
\text { ber } \\
\text { of } \\
\text { varia } \\
\text { bles }\end{array}$ & $\begin{array}{c}\text { Balan } \\
\text { ce_- } \\
\text { Avera } \\
\text { ge } \\
\text { predic } \\
\text { tion } \\
\text { accura } \\
\text { cy }\end{array}$ \\
\hline 1 & 0.5 & 35 & 0.9307 & 13 & 0.9147 & 30 & $\begin{array}{c}0.923 \\
2\end{array}$ & 14 & $\begin{array}{c}0.916 \\
5\end{array}$ \\
\hline 2 & 0.55 & 27 & 0.9283 & 13 & 0.9140 & 27 & $\begin{array}{c}0.926 \\
7\end{array}$ & 13 & $\begin{array}{c}0.923 \\
3\end{array}$ \\
\hline 3 & 0.6 & 24 & 0.9120 & 10 & 0.9238 & 30 & $\begin{array}{c}0.922 \\
3 \\
\end{array}$ & 10 & $\begin{array}{c}0.921 \\
8 \\
\end{array}$ \\
\hline 4 & 0.65 & 28 & 0.9264 & 13 & 0.9195 & 27 & $\begin{array}{c}0.934 \\
9\end{array}$ & 13 & $\begin{array}{c}0.919 \\
7\end{array}$ \\
\hline 5 & 0.7 & 32 & 0.9276 & 14 & 0.9383 & 31 & $\begin{array}{c}0.934 \\
1 \\
\end{array}$ & 14 & $\begin{array}{c}0.930 \\
6 \\
\end{array}$ \\
\hline 6 & 0.75 & 29 & 0.9041 & 14 & 0.9265 & 30 & $\begin{array}{c}0.905 \\
8\end{array}$ & 15 & $\begin{array}{c}0.923 \\
9\end{array}$ \\
\hline 7 & 0.8 & 34 & 0.9279 & 15 & 0.9240 & 33 & $\begin{array}{c}0.920 \\
8 \\
\end{array}$ & 15 & $\begin{array}{c}0.921 \\
3 \\
\end{array}$ \\
\hline 8 & 0.85 & 33 & 0.8983 & 16 & 0.9038 & 30 & $\begin{array}{c}0.904 \\
8\end{array}$ & 15 & $\begin{array}{c}0.904 \\
8\end{array}$ \\
\hline 9 & 0.9 & 28 & 0.9306 & 13 & 0.9306 & 29 & $\begin{array}{c}0.935 \\
0\end{array}$ & 13 & $\begin{array}{c}0.935 \\
0\end{array}$ \\
\hline 10 & 0.95 & 27 & 0.9100 & 16 & 0.9100 & 28 & $\begin{array}{c}0.916 \\
7\end{array}$ & 16 & $\begin{array}{c}0.916 \\
7\end{array}$ \\
\hline
\end{tabular}

Table 3 lists the feature selection results under unbalanced and balanced conditions under different proportion of training sets, 5 -fold cross validation $(\mathrm{CV}=5)$ and 10 fold cross validation $(\mathrm{CV}=10)$, as well as the average prediction accuracy on the test set.

As can be seen from table 3, first, compared with the unbalanced data without balanced 
processing, the number of variables selected for features under balanced processing is less, and the number of feature screening under unbalanced processing is basically more than twice the number of variables after balanced processing, and the feature screening after balanced processing is more concise.

Second, when the sample ratio $\mathrm{K}$ in the training set is small $(\mathrm{k}<0.75)$, the average prediction accuracy of unbalanced data is higher than that of balanced data in the test set; When $\mathrm{k} 0.75$ is balanced, the accuracy in the test set is higher or the two are basically the same. The reason may be that when $\mathrm{k}$ is small, the balance processing may form interference data and affect the accurate selection of variable characteristics; When $\mathrm{k}$ is large, the advantage of balanced processing in deep mining of data information gradually appears. In general, the segmentation proportion of data set has a certain impact on the effect of feature selection and balance processing. That is, under different segmentation ratios of the training set and test set of the data, whether to balance the original data needs to consider whether the balance processing will interfere with it or provide useful information supplement for the original data.For the sample data in this paper, the segmentation ratio is greater than 0.75 , and the balance processing will not only be beneficial to the supplement of data information, but also provide a better auxiliary role for better data feature exploration.

Third, in the 10 fold cross validation, when $\mathrm{k}=0.9$, the accuracy of unbalanced and balanced test sets is the same, and the maximum is 0.935 . The characteristic variable at equilibrium is 13 , which is relatively few.The 13 characteristic variables selected to affect whether the enterprise changes or not are: the industry to which the enterprise belongs, the economic type, the proportion of foreign trade, whether the market orders are reduced, whether the traffic and logistics are not smooth, whether the delayed commencement affects the orders, whether the market demand of products is restrained, whether the upstream supply chain such as raw materials is broken, the increase of import and export orders in the first half of 2020 The increase of import and export orders in the second half of 2020, the expected emotional characteristics of enterprises for import and export orders in 2021, whether to accelerate the research and development of new products and services, and the labor cost of relocation of enterprises.

In order to further test the robustness of variable screening, the full data set (sample size 413) is used as the training set for feature selection. After balancing, 18 variables are selected, and the 
XGBoost classification model is established based on these 18 variables. The prediction accuracy is 0.9351 , which is basically the same as that of 13 variables, The screening effect of 13 variables under the above balance treatment is relatively stable.

\section{（四）Analysis of enterprise relocation based on Probit model}

\section{Model setting}

According to the above characteristics, 13 selected variables that affect the relocation of enterprises are selected. Further, the Probit model is used to analyze the influence of COVID-19 and Sino US trade frictions on the relocation behavior of enterprises. y indicates whether the enterprise moves out or not.In addition, the natural logarithm of the enterprise's industry, economic type, foreign trade proportion, reduction of market orders, poor transportation and logistics, whether delayed commencement affects orders, whether the market demand for products is restrained, whether upstream supply chains such as raw materials are broken, whether the $\mathrm{R}$ \&amp; D of new products and services and the labor cost of the enterprise's relocation are accelerated, And the emotional characteristics of the enterprise's prediction of 2021 import and export orders. These variables are used as influencing variables. Build benchmark probit model

(Model I) , The model is set as follows:

$$
\begin{gathered}
y^{*}=\beta_{0}+\beta_{1} \mathrm{X}+\mu \\
y=\left\{\begin{array}{c}
0, \text { 当 } y^{*}>0 \text { 时, Indicates that the enterprise is unwilling to migrate } \\
1, \text { 当 } y^{*} \leq 0 \text { 时, Indicates that the enterprise is willing to migrate }
\end{array}\right. \\
\operatorname{Pr}(y=1)=\operatorname{Pr}\left(y^{*}>0\right)=\Phi\left(\beta_{0}+\beta_{1} \mathrm{X}\right)
\end{gathered}
$$

In formulas (1) - (3), $y^{*}$ as latent variable, Random error term $\mu$ obey standard state distribution, $\Phi$ is the standard normal cumulative distribution function, $\mathrm{X}$ is the basic factor variable.

On the basis of the above benchmark model (model I), the import and export growth in the first and second half of 2020 facing the outbreak of the epidemic and the escalating Sino US trade friction is further included in the benchmark model as a key variable, and the model II considering the impact of the import and export growth in the first and second half of 2020 is obtained.In order to further investigate the impact of import and export under external shocks, the two sub indicators 
of export and import in the first and second half of 2020 are included in the model, and the model III considering export, model IV considering import and model V considering all variables of order change are constructed respectively to further analyze the impact of control variables and order change on enterprise relocation. Models 2, 3, 4 and 5 are shown below:

$$
\begin{aligned}
\operatorname{Pr}(\mathrm{y}=1)= & \Phi\left(\beta_{0}+\beta_{1} \mathrm{X}+\beta_{2} \text { imp_expF }+\beta_{3} \text { imp_expP }\right) \\
\operatorname{Pr}(\mathrm{y}=1)= & \Phi\left(\beta_{0}+\beta_{1} \mathrm{X}+\beta_{2} \operatorname{expF}+\beta_{3} \operatorname{expP}\right) \\
\operatorname{Pr}(\mathrm{y}=1)= & \Phi\left(\beta_{0}+\beta_{1} \mathrm{X}+\beta_{2} \mathrm{impF}+\beta_{3} \mathrm{impP}\right) \\
\operatorname{Pr}(\mathrm{y}=1)= & \Phi\left(\beta_{0}+\beta_{1} \mathrm{X}+\beta_{2} \mathrm{imp}{ }_{-} \operatorname{expF}++\beta_{3} \operatorname{expF}+\beta_{4} \mathrm{impF}\right. \\
& \left.+\beta_{5} \text { imp_expP+}+\beta_{6} \operatorname{expP}+\beta_{7} \text { impP }\right)
\end{aligned}
$$

In this, imp_expF and imp_expP Changes in import and export orders in the first half and second half of 2020 respectively, expF and expP Changes in export orders in the first and second half of 2020, impF and impP Changes in import orders in the first half and second half of 2020 respectively.

\section{Result analysis}

According to the settings of models I, II, III, IV and V above, the corresponding probit model is established and the parameters are estimated. The estimation results are shown in Table 4 below.

It can be seen from table 4 that in the benchmark model (model I), when the significance level is $10 \%$, the economic type, the proportion of foreign trade, whether to accelerate the research and development of new products and services, the labor cost of enterprise relocation, the reduction of market orders, poor transportation and logistics, delayed commencement, and the emotional attitude towards 2021 orders have a significant impact on enterprise relocation.Among them, economic type, proportion of foreign trade, labor cost of enterprise relocation, reduction of market orders, poor transportation and logistics and delayed commencement have a positive impact on enterprise relocation, The enterprises that accelerate the research and development of new products and services have a negative impact on the relocation, and the "optimistic" and "unchanged" attitudes towards 2021 orders have a negative impact on the relocation of enterprises, Enterprises with a "pessimistic" attitude have a positive impact on enterprise relocation. The influence characteristics of these variables have been well continued in models $2,3,4$ and 5, and the action characteristics of variables are relatively stable.

On the basis of model 1, model 2 further incorporates the expected growth rate of import and 
export in the first and second half of 2020. From the regression results, under the $5 \%$ significance level, the import and export growth in the first and second half of the year has a significant impact on the relocation of enterprises. The impact coefficient in the first half of the year is negative and the impact coefficient in the second half of the year is positive. That is, the expected increase in import and export in the first and second half of the year reflects two distinct effects on the relocation of enterprises. In the first half of the year, due to import and export inertia and other factors, there was a positive correlation between enterprise relocation and import growth. With the delay of time, import and export inertia gradually disappeared under the effects of epidemic blockade and trade friction around the world, and then there was a negative correlation between enterprise relocation and import and export growth, that is, with the increase of import and export growth, enterprise relocation will slow down or delay.

Model 3 is based on Model 1 and includes the expected export growth of enterprises in the first half and second half of 2020. At the significance level of $10 \%$, the export growth in the first half of 2020 has a significant negative impact on enterprise relocation, that is, the increase of export growth will reduce enterprise relocation, and the inertia effect of export is not reflected, that is, the export inertia is seriously blocked.Similarly, when the significance level is $10 \%$, the export growth in the second half of 2020 also has a significant negative impact on the relocation of enterprises, and the increase of export will reduce the willingness of enterprises to relocate.

Model 4 is based on the benchmark model, considering the impact of import growth on enterprise relocation in the first and second half of 2020.The results show that under the $10 \%$ significance level, the variable test of import growth is not significant.Among the control variables, the impact of reduced market orders, poor transportation and logistics, delayed commencement and emotional attitude towards 2021 orders on enterprise relocation is consistent with the benchmark model in terms of significance and symbol.

The fifth model is a full variable model that includes the variables of import and export, the expected increase of export and import, as well as the decrease of market orders.From the aspect of variable significance, when the significance level is $10 \%$, the emotional characteristics dummy variables of market order reduction, poor transportation and logistics, delayed commencement and 2021 orders are similar to those of model I, II, III and IV, which have a significant impact on enterprise relocation, and the overall characteristics of the model are relatively stableIn addition, 
the disruption of upstream supply chains such as raw materials and the inhibition of market demand for products also have a significant impact on enterprise relocation.In terms of import and export, export and import growth, the overall import growth in the first and second half of 2020 has no significant impact on the relocation of enterprises,However, both import and export growth have a significant impact on enterprise relocation, and the export growth in the first and second half of the year has a negative effect on enterprise relocation, that is, with the increase of export,Slow down or postpone the relocation of enterprises, while the import and export growth in the first and second half of the year has a positive and negative impact on the relocation of enterprises. The positive in the first half of the year is mostly due to the import and export inertia factor, while the negative in the second half of the year is due to the gradual disappearance of import and export inertia with the increasing global epidemic and trade friction. Therefore, with the decrease of import and export growth, the relocation of enterprises intensifies.

Table 4 Regression results of probit model for enterprise relocation

\begin{tabular}{|c|c|c|c|c|c|}
\hline variable & Model I & Model II & Model III & Model IV & Model V \\
\hline Indust & $\begin{array}{c}0.0191 \\
(0.054)\end{array}$ & $\begin{array}{l}0.0111 \\
(0.934)\end{array}$ & $\begin{array}{c}0.0023 \\
(0.004)\end{array}$ & $\begin{array}{c}0.0046 \\
(0.006)\end{array}$ & $\begin{array}{c}0.0008 \\
(0.005)\end{array}$ \\
\hline Ecot & $\begin{array}{c}0.1106^{* *} \\
(0.127)\end{array}$ & $\begin{array}{c}0.5964 * * \\
(0.295)\end{array}$ & $\begin{array}{c}0.4903 * * \\
(0.235)\end{array}$ & $\begin{array}{c}0.5636 * * \\
(0.285)\end{array}$ & $\begin{array}{c}0.4623^{* *} \\
(0.197)\end{array}$ \\
\hline $\ln f t w$ & $\begin{array}{l}0.3057^{*} \\
(0.400)\end{array}$ & $\begin{array}{l}0.3848^{*} \\
(0.219)\end{array}$ & $\begin{array}{l}0.3777^{*} \\
(0.202)\end{array}$ & $\begin{array}{l}0.6717^{*} \\
(0.377)\end{array}$ & $\begin{array}{l}0.3448^{*} \\
(0.226)\end{array}$ \\
\hline inov & $\begin{array}{c}-0.0023 * \\
(0.001)\end{array}$ & $\begin{array}{c}-0.0021 * \\
(0.001)\end{array}$ & $\begin{array}{l}0.0059^{*} \\
(0.002)\end{array}$ & $\begin{array}{l}0.0052^{*} \\
(0.003)\end{array}$ & $\begin{array}{l}0.0098^{*} \\
(0.006)\end{array}$ \\
\hline force & $\begin{array}{c}0.0554 * * \\
(0.028)\end{array}$ & $\begin{array}{c}0.0277 * * * \\
(0.005)\end{array}$ & $\begin{array}{c}0.0212 * * * \\
(0.005)\end{array}$ & $\begin{array}{c}0.07326^{* * *} \\
(0.019)\end{array}$ & $\begin{array}{c}0.1329 * * * \\
(0.026)\end{array}$ \\
\hline order_D & $\begin{array}{c}0.2154^{* *} \\
(0.131)\end{array}$ & $\begin{array}{c}0.2561 * * \\
(0.136)\end{array}$ & $\begin{array}{c}0.2245^{* *} \\
(0.132)\end{array}$ & $\begin{array}{c}0.2134 * * \\
(0.124)\end{array}$ & $\begin{array}{l}0.1717^{*} \\
(0.124)\end{array}$ \\
\hline trans_U & $\begin{array}{c}0.2791 * * * \\
(0.137) \\
\end{array}$ & $\begin{array}{c}0.2872^{* *} \\
(0.155) \\
\end{array}$ & $\begin{array}{c}0.2762^{* *} \\
(0.158) \\
\end{array}$ & $\begin{array}{c}0.2787 * * \\
(0.153) \\
\end{array}$ & $\begin{array}{l}0.1271^{*} \\
(0.144) \\
\end{array}$ \\
\hline delay_O & $\begin{array}{l}0.3347^{*} \\
(0.185) \\
\end{array}$ & $\begin{array}{l}0.3416^{*} \\
(0.202)\end{array}$ & $\begin{array}{l}0.3284^{*} \\
(0.183)\end{array}$ & $\begin{array}{l}0.3633^{*} \\
(0.187)\end{array}$ & $\begin{array}{l}0.3557^{*} \\
(0.182)\end{array}$ \\
\hline supply_R & $\begin{array}{c}0.1665 \\
(0.214)\end{array}$ & $\begin{array}{c}0.0253 \\
(0.198)\end{array}$ & $\begin{array}{c}0.0387 \\
(0.201)\end{array}$ & $\begin{array}{c}0.0175 \\
(0.217) \\
\end{array}$ & $\begin{array}{l}0.4481^{*} \\
(0.255)\end{array}$ \\
\hline demand_M & $\begin{array}{c}0.1501 \\
(0.184)\end{array}$ & $\begin{array}{c}0.0024 \\
(0.217)\end{array}$ & $\begin{array}{l}0.3510^{*} \\
(0.186)\end{array}$ & $\begin{array}{l}0.3329^{*} \\
(0.185)\end{array}$ & $\begin{array}{l}0.3665^{*} \\
(0.189)\end{array}$ \\
\hline futureO & $\begin{array}{c}1.1253^{* * *} \\
(0.295)\end{array}$ & $\begin{array}{c}1.1212 * * * \\
(0.303)\end{array}$ & $\begin{array}{c}1.1646^{* * * *} \\
(0.302)\end{array}$ & $\begin{array}{c}1.1327 * * * \\
(0.297)\end{array}$ & $\begin{array}{l}0.6578^{*} \\
(0.343) \\
\end{array}$ \\
\hline imp_expF & & $\begin{array}{c}-0.0197^{* *} \\
(0.004)\end{array}$ & & & $\begin{array}{c}-0.0137^{*} \\
(0.008)\end{array}$ \\
\hline $\operatorname{expF}$ & & & $\begin{array}{c}-0.0097^{*} \\
(0.004)\end{array}$ & & $\begin{array}{l}-0.017^{*} \\
(0.009)\end{array}$ \\
\hline $\mathrm{impF}$ & & & & $\begin{array}{c}0.0032 \\
(0.004)\end{array}$ & $\begin{array}{l}-0.0108 \\
(0.009)\end{array}$ \\
\hline
\end{tabular}




\begin{tabular}{c|c|c|c|c|c}
\hline imp_expP & & $\begin{array}{c}0.0210^{* *} \\
(0.009)\end{array}$ & & & $\begin{array}{c}0.0337 * * \\
(0.013)\end{array}$ \\
\hline expP & & & $\begin{array}{c}-0.0023 * \\
(0.004)\end{array}$ & $\begin{array}{c}-0.0014^{*} \\
(0.001)\end{array}$ \\
\hline impP & & & & $\begin{array}{c}-0.0007 \\
(0.005)\end{array}$ & $\begin{array}{c}-0.0165 \\
(0.01)\end{array}$ \\
\hline $\begin{array}{c}\text { Log-Likeliho } \\
\text { od }\end{array}$ & -99.404 & -99.077 & -99.124 & -99.384 & -86.683 \\
\hline Pseudo $R^{2}$ & 0.02412 & 0.02075 & 0.02123 & 0.02391 & 0.1069 \\
\hline 观测值 & 413 & 413 & 413 & 413 & 413 \\
\hline
\end{tabular}

注: * 、**and***It means significant at the level of $10 \%, 5 \%$ and $1 \%$, respectively, and the standard error in parentheses.

Overall, according to the regression results from model 1 to model 5, under the dual influence of the epidemic and Sino US trade friction, the relocation of enterprises is significantly affected by the reduction of market orders, poor transportation and logistics, delayed commencement, changes in import and export growth in the first and second half of 2020, as well as the expected emotional characteristics of 2021 orders.Among them, the order changes related to market demand, upstream and downstream supply chains and future expectations are the key factors affecting whether enterprises move out.

\section{七、Conclusion}

With the impact of the global epidemic, the world economy and trade continue to be in a downward cycle, coupled with multiple pressures such as trade protectionism and anti globalization under Sino-US friction, Chinese enterprises are facing a variety of adverse situations, such as the reduction of short-term orders, the inhibition of product market demand, poor transportation and logistics, delayed commencement, the disruption of upstream supply chains such as orders and raw materials, Enterprises face multiple difficulties in production, operation and sustainable development. Therefore, the problem of enterprise relocation under the external impact has gradually attracted the keen attention of the academic circles.

Based on the sample data of enterprise relocation survey, with the help of the feature selection method in machine learning, considering the unbalanced characteristics of data, this paper makes a feature selection analysis of the influencing variables of enterprise relocation, and makes a comparative study on the feature selection results without balance processing and after balance processing.After analysis, comparison and robustness test, 13 important characteristic 
variables affecting the relocation of enterprises are selected from 102 index data.On the basis of this, we further analyze the influence of COVID-19 and Sino US trade frictions on the migration behavior of enterprises by further analyzing the Probit model.The results show that the growth of import and export in the first and second half of 2020 has a significant impact on the relocation of enterprises. Among them, the growth of import and export in the first and second half of 2020 has a positive and negative impact on the relocation of enterprises,Export growth has a negative effect on enterprise relocation, that is, with the increase of export, it will slow down or delay enterprise relocation. In addition, the economic type, the proportion of foreign trade, whether to speed up the research and development of new products and services, the labor cost of the relocation of enterprises, whether the market orders are reduced, whether the transportation and logistics are smooth and whether the commencement is delayed, and the emotional attitude towards 2021 orders all have a significant impact on the relocation of enterprises.

The rainbow is always after the storm. The difficulties are temporary and the future is good.With the continuous recovery of China's economy under the control of the epidemic, relatively many enterprises are "optimistic" about the expectation of 2021 in the survey data. With the continuous implementation of relief funds, tax relief and other policies, the vitality of enterprises is increasingly showing, The continuous recovery and growth of foreign trade, especially the successful holding of the China International Fair and the rapid growth of China's economy in the first quarter of 2021, have laid a solid foundation for the "dominance" of China's economy under the global impact of the epidemicThe good control of the epidemic and the stable economic environment not only slow down the relocation of enterprises, but also further provide important help for retaining enterprises and attracting foreign enterprises.In addition, we will unswervingly promote reform and opening up and implement flexible and effective foreign trade measures, continue to improve the business environment, adjust the foreign trade structure, further increase support for innovation, enhance the "hard power" of science and technology, and constantly move from the low end of the value chain to the middle and high end,It is also the key core for China to retain enterprises and attract foreign enterprises in the future. With the regional socio-economic development and the in-depth expansion of the double cycle mechanism, the impact of external impact will continue to weaken, and more enterprises will move in or "move back" will be expected. 


\section{Statements}

\section{Funding}

The authors declare that no funds, grants, or other support were received during the preparation of this manuscript

\section{Competing Interests}

Authors have no relevant financial or non-financial interests to disclose.

\section{Author Contributions}

All authors contributed to the study conception and design. Material preparation, data collection and analysis were performed by xia mao-sen, zhu chang-hao and jiang ling-ling. The first draft of the manuscript was written by xia mao-sen and all authors commented on previous versions of the manuscript.

\section{Informed Consent}

All authors read and approved the final manuscript.

\section{Data Availability}

The datasets generated during the current study are not publicly available due to crawling the site to get but are available from the corresponding author on reasonable request.

\section{Reference}

[1]Ling Yong-hui, Zhang Yue-you, Shen Kai-ling,Producer Services Development, Advanced Manufacturing Efficiency Promotion and Industrial Interaction: an Empirical Study Based on Panel Simultaneous Equations Model[J].Contemporary economic science,2017( 2): 62-71,126.

[2]Wang Xiao-juan. A Study on the Reason and Effect of Enterprises Moving out of Industrial Clusters [J].Journal of Chongqing University (SOCIAL SCIENCE EDITION),2006(01):22-27.

[3]Isard W. Location and space economy[J]. Cambridge Massachusetts: The M.I.T.Press, 1956.

[4]Li Yan-jun, Xie Shang On Decision of Enterprise Migration and lnfluencing Factors[J].Journal of South-central University for Nationalities (Humanities and Social Sciences Edition),2018,38(03):150-155. 
[5]Zheng Xin, Chen Yao.Transport Cost,Demand Distribution and Industrial Relocation-Analysis of a Model Based on Location Theory[J]. China Industrial Economics,2012(02):57-67.

[6]Masahisa Fujita,Paul Krugman,Anthony J.Venables.Spatial Economics — cities, regions and international trade[M].Beijing:China Renmin University Press, 2011, (Chinese Translation):52, 187-191.

[7]Xu Li-ping, Wang Ying-zhuo, Liu Ning, Zhang Shu-xia. Local government environmental regulation and enterprise migration behavior -- from the cost perspective of Chinese industrial enterprise database samples[J].Financial theory and Practice,2019,40(04):81-87.

[8]Liang Qi, DING Shu, Wang Ruyu. Headquarters cluster and factory location[J].Economics (quarterly),2012,11(03):1137-1166.

[9]Liminta L G. Firm migration and high skilled migration flows: a new simple and comparable indicator[J]. 2018.

[10] Plant R. An empirical analysis: Venture capital clusters and firm migration[J]. Journal of Developmental Entrepreneurship, 2007, 12(02): 139-163.

[11]Liu Zhen-zhong.A Study on the Impact and Mechanism of Manufacturing Migration on Producer Service: An Example from Guangdong Province[J].Macroeconomics,2020(09):5-21+35.

[12]Wu Bo.Are High-level Cluster Firms More Likely to Relocate?[J].R\&D Management,2013,25(02):29-36.

[13]Lin Bi-yue, ye Xiao-jie.Strategic Decisions and Economic Consequences of the Private Enterprises'Headquarters Relocation:An Empirical Study in China[J].Journal of Central University of Finance \& Economics,2012(11):73-79.

[14]Xu Liang.Review of Enterprise Migration Research[J].Journal of Yancheng Institute of Technology(Social Sciences Edition),2014,27(02):34-37.

[15]Li Yan-jun, DAI Feng-yan, LI Bao-xia, PANG Jing.An empirical study on the influence of policy factors on migration decision of resource-based enterprises[J].China Population,Resources and Environment,2015,25(06):135-141.

[16]Yang Ben-jian,Mao Yan-hua.Industrial Relocation Policy and Firm Migration:an Empirical Analysis from Guangdong Industrial Relocation Survey Data[J].South China Journal of Economics,2014(03):1-20. 
[17]Nachtigall D. Dynamic Climate Policy Under Firm Relocation: The Implications of Phasing Out Free Allowances[J]. Environmental and Resource Economics, 2019, 74(1): 473-503.

[18]Wang Ding-xing Zhang Jing.Impact of Environmental Regulation on Surviving Firms' Migration[J].Technology Economics ,2019,38 (12):31-41.

[19]Zhou Zheng-zhu, Sun Ming-gui, Zhang Ying.Influencing factors of enterprise migration location choice[J].Research on Economics and Management,2015,36(04): 110-119.

[20]Yang Kai-zhong,Dong Yan-ning,Gu Yun.The influence of transport costs and heterogeneous enterprise migration on regional balanced development_-Analysis based on the theory of interation on spatial agglomeration and endogenous growth[J].System Engineering Theory and Practice,2019,39(10):2466-2475. 